\title{
TINJAUAN PELANGGARAN HAK DAN PENGINGKARAN KEWAJIBAN WARGA NEGARA BERDASARKAN UUD 1945
}

\author{
Siti Zikrina Farahdiba, Nisrina Nur Sa'idah, Desmi Salsabila \& Siti Nur'aini \\ Universitas Islam Negeri Walingo Semarang \\ Email:2108096004@student.walisongo.ac.id,2108096026@student.walisongo.ac.id, \\ 2108096028@student.walisongo.ac.id
}

\begin{abstract}
Abstrak
Tujuan dari literatur ini adalah supaya masyarakat mengerti tetang hak dan kewajiban dalam bewarga negara di Indonesia. Serta mengerti tentag fakto-faktor apa saja yang menybabkan pelanggaran hal dan pengingkaran kewajiban warga negara. Metode penulisan yang dilakukan menggunakan metode penulisan kepustakaan (library research). Pemahaman hak dan kewajiban ini harus dimiliki oleh setiap warga negara. Tujuannya adalah untuk memastikan semua warga negara bisa menghargai hak diri sendiri dan orang lain serta melakukan kewajibannya. Pelanggaran hak warga negara terjadi ketika warga negara tidak dapat menikmati atau memperoleh haknya sebagaimana mestinya yang ditetapkan oleh undang-undang. Pelanggaran hak warga negara merupakan akibat dari adanya pelalaian atau pengingkaran terhadap kewajiban, baik yang dilakukan oleh pemerintah maupun oleh warga negara sendiri.
\end{abstract}

Kata kunci: kewajiban warga negara, Hak warga negara, UUD 1945

\begin{abstract}
The purpose of this study is for people to understand the meaning of the civic right and civic duties in Indonesia as well as to make them understand the factors that cause violation of the rights and obligations of citizens. This study used Literary methods (library research). All citizens must understand these rights and obligations so that they can respect the rights of themselves and others and fulfill them. Abuse of citizens' rights occurs when they can't enjoy and get their rights. Even though the rights of citizens are already regulated in the Constitution of Indonesia. Violation of the citizen's right is the result of negligence or denial of obligations, whether carried out by the government or by citizens.
\end{abstract}

keayword: civic duties, civic right, constitution of indonesia.

\section{PENDAHULUAN}

Sebagai warga negara Indonesia, hendaknya kita memahami arti dari hak dan kewajiban. Dengan tujuan agar setiap warga negara dapat tanggung jawab dengan hak dan kewajibannya masing-masing. Namun dalam kenyataannya, masih banyak warga negara yang yang melanggar haknya dan mengingkari kewajibannya yang akhirnya merugikan diri sendiri, orang lain, bahkan negara.

Secagai contoh kasus dari
pelanggaran hak ialah menangkap seseorang demi menjaga stabilitas tanpa didasari hukum. Hal itu telah melanggar haknya sebagai aparatur negara, sebab dalam proses penangkapan harus didasari dengan hukum yang jelas bukan hanya untuk menjaga stabilitas semata. Sementara, contoh dari kasus pengingkaran kewajiban sebagai warga negara ialah tidak membayar pajak. Sebagai warga Indonesia kita memiliki kewajiban membayar pajak kepada negara. Apabila kita tidak melakukannya maka kita telah mengingkari kewajiban sebagai warga Indonesia.

Pengingkaran kewajiban dapat terjadi karena adanya pelanggaran hak. Banyak faktor yang menyebabkan seseorang dapat melanggar hak dan mengingkari kewajibannya. Pelanggaran hak warga negara merupakan akibat dari kelalaian atau pengingkaran kewajiban, baik yang dilakukan oleh pemerintah maupun oleh warga negara itu sendiri. Oleh karena itu, perlu dilakukan tindakan untuk 
menghilangkan adanya pelanggaran hak dan pengingkaran kewajiban sebagai warga negara.

Oleh Sebab itu, kami mengambil tema ini sebagai bahan penelitian kami. Agar kami dan pembaca dapat memahami pengertian dari hak dan kewajiban, mengetahui faktor-faktor penyebab terjadinya pengingkaran hak dan pelanggaran kewajiban, serta bentuk kasus dari pelanggaran hak dan pengingkaran kewajiban itu sendiri. Serta dapat mengetahui upaya dalam menghilangkan pelanggaran hak dan pengingkaran kewajiban warga negara di Indonesia.

Hak dan kewajiban warga negara mempunyai hubungan timbal balik dengan hak dan kewajiban negara. Di sisi lain, hak negara diterjemahkan menjadi kewajiban yang mutlak dihormati oleh warga negara. Misalnya, jika setiap warga negara berhak atas pendidikan, maka negara wajib menyediakan fasilitas pendidikan bagi warganya. Sebaliknya, jika negara berhak untuk dibela oleh setiap warga negara, maka warga negara berkewajiban untuk membela negara. Dalam UUD 1945, hak dan kewajiban warga negara Indonesia serta hak dan kewajiban negara Indonesia diatur dalam Pasal 27 sampai dengan 34 yang meliputi bidang: politik dan pemerintahan, sosial, agama, pendidikan, dan pertahanan.

Pelanggaran hak warga negara terjadi pada saat warga negara tidak dapat menikmati atau memperoleh haknya sebagaimana seharusnya diatur oleh undang-undang. Pelanggaran hak warga negara merupakan akibat dari kelalaian atau pengingkaran kewajiban, baik yang dilakukan oleh pemerintah maupun oleh warga negara itu sendiri. Misalnya kemiskinan yang masih menimpa sebagian masyarakat Indonesia, penyebabnya bisa dari pemerintah ketika program pembangunan tidak berjalan sebagaimana mestinya, atau bisa juga karena perilaku warga yang sama yang malas bekerja atau tidak mau bekerja. memiliki keterampilan untuk hidup di garis kemiskinan.

Kesadaran berbangsa dan bernegara artinya sikap dan perilaku harus sesuai dengan kepribadian bangsa dan selalu berkorelasi dengan cita-cita dan tujuan hidup bangsa Indonesia (sesuai amanat yang terkandung dalam Pembukaan UUD 1945). Penerapan Hak dan Kewajiban, tindakan terbaik dalam menegakkan hak dan kewajiban warga negara adalah mencegah segala faktor yang menyebabkan terjadinya pelanggaran hak dan pengingkaran kewajiban warga negara.

\section{METODE PENELITIAN}

Penulis telah menggunakan metode penulisan kepustakaan (library research). Penelitian kepustakaan adalah penelitian yang dilakukan dengan menggunakan literatur (kepustakaan), baik berupa buku, catatan, maupun laporan hasil penelitian terdahulu. Penelitian yang dilakukan termasuk penelitian kausalitas kuantitatif.

\section{HASIL PENELITIAN DAN PEMBAHASAN Hasil Penelitian}

\section{A. Pengertian Hak dan Warga Negara}

Menurut Prof. Dr. Notonegoro hak adalah suatu kekuasaan untuk menerima atau melakukan sesuatu yang seharusnya diterima atau dilakukan. Dalam hal ini, tidak dapat dilakukan atau diterima oleh pihak lain. Dan kewajiban adalah sebagai kewajiban untuk memberikan sesuatu yang harus diberikan dari bagian tertentu. Dalam hal ini tidak dapat diberikan oleh pihak lain dan dapat digugat dengan kuat jika tidak puas. Kewajiban juga diartikan sebagai sesuatu yang harus dilakukan.

Sedangkan menurut Prof. R.M.T. Sukamto Notonagoro, hak adalah suatu kuasa untuk menerima atau melakukan sesuatu yang seharusnya diterima atau dilakukan. Dalam hal ini tidak dapat dilakukan dan diterima oleh pihak lain. Hak dan kewajiban warga negara, keduanya 
dapat dipaksakan oleh subjek data. Sedangkan kewajiban menurut prof. R.M.T. Sukamto Notonagoro adalah sesuatu yang perlu dilakukan oleh beberapa pihak dan dapat digugat secara paksa oleh pihak yang berkepentingan. Kewajiban dapat timbul karena adanya keinginan untuk diri sendiri dan orang lain. Kewajiban ini dapat timbul dari hak yang dimiliki oleh orang lain.

Berdasarkan pendapat para ahli di atas, dapat kita pahami bahwa hak warga negara adalah kekuasaan warga negara untuk melakukan sesuatu berdasarkan hukum. Dengan kata lain, hak warga negara merupakan hak istimewa yang mengharuskan warga negara diperlakukan sesuai dengan hak istimewa tersebut. Kewajiban warga negara bersifat wajib, tetapi tidak boleh ditinggalkan oleh warga negara dalam kehidupan bermasyarakat berbangsa dan bernegara. Kewajiban warga negara juga dapat diartikan sebagai sikap atau tindakan yang harus dilakukan warga negara sesuai dengan keistimewaan warga negara lainnya.

Hak dapat dibedakan menjadi dua, yaitu hak umum atau hak kodrati dan hak khusus atau hak hukum. Hak secara umum adalah apa yang kita ketahui tentang hak. Sedangkan hak khusus adalah hak yang telah diatur oleh negara dalam ketentuan khusus dan mempunyai batasan hukum. Kewajiban bisa disebut kebutuhan. Selanjutnya, kita juga dapat memahami hak sebagai tanggung jawab. Kewajiban adalah sesuatu yang harus dilakukan karena itu adalah tanggung jawab kita. Jika tidak, hukuman atau konsekuensi akan diterapkan.

Memahami hak dan kewajiban tersebut harus menjadi milik setiap warga negara. Tujuannya adalah untuk memastikan bahwa semua warga negara dapat menghormati hak mereka sendiri dan orang lain dan memenuhi kewajiban mereka.

\section{Pembahasan}

Hak dan kewajiban warga negara menurut UUD 1945 pasal 27 - 31.

Hak Warga Negara Menurut UUD 1945.

1) Pasal 27 ayat 2 dan 3:

1. Tiap-tiap warga negara berhak atas pekerjaan dan penghidupan yang layak bagi kemanusiaan.

2. Setiap warga negara berhak dan wajib ikut serta dalam upaya pembelaan negara.

2) Pasal 28A:

Setiap orang berhak untuk hidup serta berhak mempertahankan hidup dan kehidupannya.

3) Pasal 28B ayat 1 dan 2:

1. Setiap orang berhak membentuk keluarga dan melanjutkan keturunan melalui perkawinan yang sah.

2. Setiap anak berhak atas kelangsungan hidup, tumbuh, dan berkembang serta berhak atas perlindungan dari kekerasan dan diskriminasi.

4) Pasal 28C ayat 1 dan 2:

1. Setiap orang berhak hidup sejahtera lahir dan batin, bertempat tinggal, dan mendapatkan lingkungan hidup baik dan sehat serta berhak memperoleh pelayanan kesehatan.

2. Setiap orang mendapat kemudahan dan perlakuan khusus untuk memperoleh kesempatan dan manfaat yang sama guna mencapai persamaan dan keadilan.

5) Pasal 28D ayat 1,2 dan 3:

1. Setiap orang berhak atas pengakuan, jaminan, perlindungan, dan kepastian hukum yang adil serta perlakuan yang sama di hadapan hukum.

2. Setiap orang berhak untuk bekerja serta mendapatkan imbalan dan perlakuan yang adil dan layak dalam hubungan kerja. 
3. Setiap warga negara berhak memperoleh kesempatan yang sama dalam pemerintahan.

6) Pasal 28E ayat 1,2 dan 3:

1. Setiap orang bebas memeluk agama dan beribadat menurut agamanya, memilih pendidikan dan pengajaran, memilih pekerjaan, memilih kewarganegaraan, memilih tempat tinggal diwilayah negara dan meninggalkannya, serta berhak kembali.

2. Setiap orang atas kebebasan meyakini kepercayaan, menyatakan pikiran dan sikap, sesuai dengan hati nuraninya.

3. Setiap orang berhak atas kebebasan berserikat, berkumpul, dan mengeluarkan pendapat.

7) Pasal 28F:

Setiap orang berhak untuk berkomunikasi dan memperoleh informasi untuk mengembangkan pribadi dan lingkungan sosialnya, serta berhak untuk mencari, memperoleh, memiliki, menyimpan, mengolah, dan menyampaikan informasi dengan menggunakan segala jenis saluran yang tersedia.

8) Pasal 28G ayat 1 dan 2:

1. Setiap orang berhak atas perlindungan diri pribadi, keluarga, kehormatan, martabat, dan harta benda yang dibawah kekuasaannya, serta berhak atas rasa aman dan perlindungan dari ancaman ketakutan untuk berbuat atau tidak berbuat sesuatu yang merupakan hak asasi.

2. Setiap orang berhak untuk bebas dari penyiksaan dan perlakuan yang merendahkan derajat martabat manusia dan berhak memperoleh suaka politik dari negara lain.

9) Pasal 28H:

1. Setiap orang berhak hidup sejahtera lahir dan batin, bertempat tinggal, dan mendapatkan lingkungan hidup baik dan sehat serta berhak memperoleh pelayanan kesehatan.

2. Setiap orang mendapat kemudahan dan perlakuan khusus untuk memperoleh kesempatan dan manfaat yang sama guna mencapai persamaan dan keadilan.

Kewajiban Warga Negara Menurut UUD 1945.

1) Pasal 27 ayat 1 dan 3 :

1. Segala warga negara bersamaan kedudukannya di dalam hukum dan pemerintahan dan wajib menjunjung hukum dan pemerintahan itu dengan tidak ada kecualinya.

2. Setiap warga negara berhak dan wajib ikut serta dalam upaya pembelaan negara.

2) Pasal 28J ayat 1 dan 2:

1. Setiap orang wajib menghormati hak asasi manusia orang lain dalam tertib kehidupan bermasyarakat, berbangsa, dan bernegara.

2. Dalam menjalankan hak dan kebebasannya, setiap orang wajib tunduk kepada pembatasan yang ditetapkan dengan undang-undang dengan maksud semata mata untuk menjamin pengakuan serta penghormatan atas hak kebebasan orang lain dan untuk memenuhi tuntutan yang adil sesuai dengan pertimbangan moral, nilai-nilai agama, keamanan, dan ketertiban umum dalam suatu masyarakat demokratis.

3) Pasal 30 ayat 1 :

Tiap-tiap warga negara berhak dan wajib ikut serta dalam usaha pertahanan dan keamanan negara.

4) Pasal 31 ayat 2:

Setiap warga negara wajib mengikuti pendidikan dasar dan pemerintah wajib membiayai nya. 


\section{Penyebab Terjadinya Pelanggaran Hak dan Pengingkaran Kewajiban Warga Negara}

Pelanggaran hak warga negara dapat terjadi ketika warga negara tidak dapat menikmati atau memperoleh haknya sebagaimana seharusnya diatur oleh undang-undang. Pelanggaran hak warga negara merupakan akibat dari kelalaian atau pengingkaran kewajiban, baik yang dilakukan oleh pemerintah maupun oleh warga negara itu sendiri (Moendoeng 2019). Di Masa modern seperti sekarang di mana semua informasi dapat diakses dan terbuka untuk umum tidak menjadi solusi untuk mengurangi terjadinya pelanggaran hak dan kewajiban yang terjadi di Indonesia.

Hal ini malah menjadi faktor terjadinya pelanggaran hak dan kewajiban. Dengan perkembangan teknologi semua orang dapat dengan bebas melihat kehidupan seseorang, Banyak darinya yang menjadi iri dan berusaha untuk mengikuti gaya hidup seseorang padahal ia tidak mampu, contoh kasusnya seseorang membeli mobil karena melihat postingan temannya dengan mobil barunya. Akhirnya orang ini tidak dapat membayar pajak karena memang tidak mampu untuk membayarnya.

Selain perkembangan zaman terdapat beberapa faktor lainnya di antaranya; pertama sikap egois Setiap orang mempunyai hak dan kewajiban, tetapi jika seseorang selalu menuntut haknya tanpa memenuhi kewajibannya, maka akan terjadi pelanggaran. Sikap egois tidak akan memikirkan orang lain dan akan melakukan apa yang diinginkannya. Seseorang dengan sikap egois akan melakukan berbagai cara agar hak-haknya dapat terpenuhi, meskipun mengabaikan hak orang lain.

Kedua sikap intoleransi, Indonesia merupakan negara dengan banyak suku budaya ras dan agama oleh karena itu dibutuhkan sikap menghormati dan menghargai seseorang tanpa memandang status dan semua perbedaan untuk menjaga Kesatuan NKRI. Ketiga kurangnya Rasa Kesadaran Berbangsa dan Bernegara, Setiap negara memiliki aturan yang tidak boleh dilanggar oleh warganya. Ketika kesadaran warga rendah dan mengabaikan aturan yang ada akan menyebabkan perbuatan buruk. Tindakan sewenangwenang dapat menimbulkan sikap menyimpang terhadap hak dan kewajiban warga negara.

Selain faktor dari sendiri (warga negara) terdapat beberapa faktor penyebab terjadi pelanggaran hak dan kewajiban yang berasal dari instalasi maupun aparat negara diantaranya; sikap Kurang Tegasnya Aparat Penegak Hukum, Aparat penegak hukum memegang peranan penting dalam bernegara dan bermasyarakat, sehingga harus tegas menanggapi permasalahan yang ada. Akan tetapi akhir akhir ini banyak terjadi kasus dimana aparat seperti menutup mata dan mengabaikan suatu persoalan yang seharusnya diadili. Hal ini menyebabkan masyarakat tidak percaya dan menyepelekan peraturan yang ada. terjadinya penyalahgunaan kekuasaan (abuse of power), Baru baru ini banyak aparat negara yang tertangkap basah melakukan penyalahgunaan kekuasaan dimana mereka memakai wewenang mereka untuk kepentingan tertentu, baik untuk kepentingan diri sendiri, maupun orang lain. Semakin tinggi jabatan seseorang semakin tinggi ke wewenangnya dan kemungkinan ia melakukan abuse of power semakin besar. Berdasarkan pengertian tersebut dapat disimpulkan bahwa abuse of power bukan hanya terjadi di pemerintahan, tetapi juga dalam bentuk lain. Misalnya, perusahaan yang tidak jujur dan mengambil hak pekerja.

\section{Kasus Pelanggaran Hak Dan Pengingkaran Kewajiban Warga Negara}




\section{Pelanggaran hak warga negara}

a) Pelanggaran Kebebasan Berpendapat.

Kebebasan berpendapat salah satu hak setiap warga negara yang telah dijamin oleh konstitusi. Negara Indonesia merupakan negara hukum dan demokratis yang berwenang untuk mengatur dan melindungi pelaksanaannya. Kebebasan berpikir dan mengeluarkan pendapat tersebut diatur dalam perubahan keempat Undang-Undang Dasar Republik Indonesia tahun 1945 Pasal 28 E ayat (3) Setiap orang berhak atas kebebasan berserikat, berkumpul, dan mengeluarkan pendapat.

Salah satu pelanggaran hak berpendapat yaitu pelanggan yang dilakukan oleh pemerintah atau kelompok individu. Adanya pelanggaran tersebut akan menghambat keinginan orang lain untuk berpendapat. Walaupun ada undangundang yang melindungi pendapat, tetapi kita harus menjaga sikap kita dalam mengutarakan pendapat, menghormati orang lain dan menjaga sopan santun.

Ancaman berpendapat bukan terjadi dari kelompok kecil, tetapi ancaman sesungguhnya berasal dari sekelompok politik yang memberikan izin kepada kita untuk mengemukakan berpendapat dan juga mencoba untuk membungkam kelompok lainnya.

Upaya untuk kebebasan berpendapat dan berekspresi dengan Pasal 310 dan 311 KUHP dapat dilakukan dengan cara penerapannya yang proporsional yaitu bukan dengan pidana penjara yang dinilai dari aspek Hak Asasi Manusia sebagai hal yang berlebihan untuk menangani persoalan kebebasan berpendapat dan berekspresi. Penghapusan pidana penjara dan mengganti dengan pidana denda dapat memberikan efek yang lebih baik bagi masyarakat. Khususnya kalangan masyarakat yang berprofesi sebagai aktivis ataupun jurnalis. b) Menggunakan budaya kekerasan atau main hakim sendiri di masyarakat

Tindakan main hakim sendiri di masyarakat dapat terjadi karena berbagai faktor. Faktor-faktor penyebab masyarakat untuk melakukan tindakan tersebut adalah kurangnya pemahaman dan kesadaran masyarakat tentang hukum, kekhawatiran masyarakat tentang kasus pencurian yang tidak pernah terungkap, penegakan hukum yang lemah, dan ketidakpercayaan masyarakat kepada penegak hukum.

Upaya aparat kepolisian dan masyarakat untuk mencegah tindakan main hakim sendiri dapat dilakukan dengan beberapa cara. Pertama, upaya preventif sebelum kejahatan terjadi. Misalnya, upaya peningkatan ketegasan polisi dalam mengatasi pencurian, pelaksanaan dan penguatan tuntunan agama, sosialisasi KAMTIBMAS oleh POLRI, Ronda tiap RT, dan patrol pada jam-jam rawan. Kedua, upaya aparat penegak hukum untuk menegakkan keadilan dalam main hakim sendiri, yaitu penyelesaian hukum oleh aparat penegak hukum secara keseluruhan.an Budaya Kekerasan atau Main Hakim Sendiri di Masyarakat

c) Pelanggaran hak asasi manusia (pemerkosaan, penculikan, pembunuhan, dll)

Di indonesia sering kali terjadi pelanggaran hak asasi manusia diantaranya seperti pemerkosaan, penculikan, pembunuhan dan kekerasan dalam rumah tangga. Padahal dalam UUD 1945 pasal 28 A-28j dijelaskan keberadaan hak asasi manusia dan dijamin keberadaannya. Untuk mengurangi terjadinya pelanggaran hak asasi manusia di butuh beberapa upaya untuk menanggulanginya, menurut Yusnawan Lubis dan Mohamad Sodeli dalam buku berjudul Pendidikan Pancasila dan Kewarganegaraan, upaya pencegahan terjadinya pelanggaran HAM dapat 
dilakukan dengan tindakan berikut ini, diantaranya;

Pertama, meningkatkan pengetahuan dan pemahaman masyarakat mengenai prinsip HAM, salah satu caranya dengan memperbaiki kualitas lembaga pendidikan formal non-formal seperti sekolah, perguruan tinggi. Kedua, melakukan penegakan demokrasi dan supremasi hukum, dalam hal ini dibutuhkan kerja sama antara aparat penegak hukum dan juga masyarakat dengan tujuan untuk meningkatkan partisipasi masyarakat dalam pencegahan HAM. Ketiga menghargai dan menghormati antar kelompok dan golongan sehingga terjadi hubungan kerja sama yang baik didalamnya. Keempat, meningkatkan pengawasan masyarakat dan lembaga politik terhadap penegakan HAM oleh pemerintah. kelima, Meningkatkan kualitas pelayanan publik. Keenam, Meningkatkan profesionalisme lembaga pertahanan dan keamanan.

\section{Pengingkaran kewajiban warga negara}

\section{a) Melanggar Peraturan Perundang- undangan.}

Seseorang yang mempunyai sifat kesadaran rendah dan bersifat egois yang selalu mementingkan dirinya sendiri. Seseorang yang mempunyai sikap seperti itu akan melakukan segala cara agar hak atau kemauannya terpenuhi, meskipun orang lain mempunyai hak yang harus dihormati dan tidak bisa dilanggar. Padahal sudah dijelaskan dalam UUD pasal 28J ayat 1 dan 2 bahwa dalam menjalankan hak dan kebebasannya, setiap orang wajib tunduk kepada pembatasan yang ditetapkan oleh undang-undang.

Upaya bagi seseorang yang melanggar peraturan perundang-undangan yaitu dengan menumbuhkan sikap rasa kesatuan dan persatuan bangsa bernegara. Serta rasa kesadaran atas tanggung jawab sebagai warga negara. Karena sejatinya bangsa Indonesia mempunyai banyak suku bangsa yang mempunyai bahasa adat istiadat yang berbeda. Kepolisian juga harus andil dalam menangani kasus pelanggaran peraturan perundang-undangan. Seperti memberikan hukum dan juga sanksi yang adil bagi pelaku.

b) Merusak Lingkungan Hidup

Manusia merupakan bagian dari komponen lingkungan hidup yang mempengaruhi dan dipengaruhi oleh alam di sekitarnya. Manusia menggunakan tanah, hutan, dan sumber daya lainnya untuk memenuhi kebutuhan mereka. Selain berhak mendapat lingkungan yang baik, manusia juga memiliki kewajiban untuk menjaga kelestariannya. Jika hak dan kewajiban dilaksanakan dengan seimbang, manusia dapat memenuhi berbagai kebutuhan dan terhindar dari bencana.

Namun nampaknya manusia agak kesulitan menjalankan kewajibannya untuk menjaga lingkungan (Nurgiansah, 2020) (Nurgiansah, 2021). Hal itu dapat terlihat dari banyaknya kasus perusakan lingkungan yang disebabkan ulah manusia itu sendiri. Hal tersebut tentu saja mengartikan bahwa seseorang tersebut telah mengingkari kewajibannya. Beberapa kasus ulah manusia yang dapat mengakibatkan kerusakan lingkungan seperti kerusakan hutan dan alih fungsi hutan, pertambangan, pencemaran udara, air, dan tanah dan lain sebagainya.

Upaya pencegahan dan penanganan dari tindak kejahatan perusakan lingkungan dapat dilakukan dengan tahap pre-emtif, preventif dan represif. Tahap pertama yang dapat dilakukan ialah melalui tahap pre-emtif dengan menanamkan nilainilai atau norma yang baik, harapannya norma tersebut dapat terinternalisasi dalam diri seseorang, sehingga mencegah seseorang berbuat kejahatan. Tahap selanjutnya dikenal sebagai tahap preventif yaitu tahapan mencegah seseorang melakukan kejahatan yang terfokus pada 
faktor luar diri manusia. Tahap terakhir disebut tahap represif, yaitu merupakan upaya penindakan melalui hukum pidana. Tahap represif dilakukan apabila tahapan pre-emtif dan preventif tidak dapat mencegah seseorang melakukan kejahatan

\section{KESIMPULAN}

Berdasarkan penelitian diatas dapat kita simpulkan bahwa penelitian ini bertujuan untuk mengetahui dan memahami hak dan kewajiban, dimulai dari pengertian, faktor faktor yang menyebabkan terjadinya pelanggaran hak dan kewajiban dan upaya yang harus dilakukan untuk meminimalisir pelanggaran hak dan kewajiban tersebut. Dengan metode penulisan kepustakaan (library research) dapat disimpulkan bahwa: Hak dan kewajiban merupakan suatu hal yang mempunyai kaitan erat dimana dalam menjalankannya harus seimbang. Setiap orang yang ingin mempunyai hak nya harus melakukan kewajibannya juga. Dimana pengertian hak itu sendiri adalah segala sesuatu yang dimiliki setiap individu sejak didalam kandungan sedangkan kewajiban memiliki arti segala tugas atau keharusan seseorang atau individu dalam menjalankan perannya guna mendapatkan haknya.
Adanya peraturan yang mengatur penjaminan hak dan kewajiban belum mampu meminimalisir terjadinya pelanggaran hak dan kewajiban secara maksimal karena nyatanya sampai sekarang masih marak terjadi pelanggaran hak dan kewajiban mulai dari yang ringan hingga pelanggaran yang berat. Hal ini menyatakan bahwa peraturan saya tidak cukup untuk menjamin hak dan kewajiban seseorang, diperlukan pemahaman dan kesadaran akan pentingnya menjalankan dan menjaga hak dan kewajiban antar individu. Untuk mencapai hal ini dibutuhkan koordinasi yang baik antara pemerintah dan masyarakat. Pemerintah harus memperbaiki kualitas aparatnya sehingga tidak ada lagi penyalahgunaan kekuasaan yang dilakukan oleh aparat pemerintah serta pemerintah juga harus memaksimalkan lembaga lembaga yang sudah ada. Masyarakat juga harus diberi pemahaman tentang pentingnya menjaga dan menghargai hak dan kewajiban bukan hanya untuk dirinya sendiri akan tetapi juga untuk hak dan kewajiban orang lain karena pada akhirnya hak kewajiban seseorang dibatasi oleh hak dan kewajiban orang lain.

\section{DAFTAR PUSTAKA}

Dwientha, D., Seriksat, N., Jaya, P., \& Purwoto. (2019). Kebijakan Hukum Pidana Dalam Upaya Penanggulangan. Diponegoro Law Journal, Volume 8, Nomor 2, 1026-1041.

Imam, N., \& Hasan, S. (2020). Retrieved from academia.edu: https://www.academia.edu/42680802/HAK_DAN_KEWAJIBAN_WARGA_NEGARA_DA LAM_KEHIDUPAN_BERBANGSA_DAN_BERNEGARA_BERDASARKAN_PANCASILA_DAN_ UUD_1945

Ii, B. A. B., and Tinjauan Pustaka. (2012). "Teori Kebutuhan Atau Kepentingan Manusia. Teori Ini Mengungkapkan Bahwa Konflik Dapat 1." 6-26.

Marliyati, Lilyk. (2019). PPKn Kelas XII: HAM Direktorat Pembinaan SMA.

Moendoeng, N. (2019). "Peran Pemerintah Dalam Mengatasi Pelanggaran Hak Dan Pengingkaran Kewajiban Warga Negara Berdasarkan UUD 1945.” Lex Et Societatis 52(1):1-5.

Mursyidik, S. (2019). "Makalah Kasus Pelanggaran Hak dan Pengin.”

Nafilah. (2020). "Hak Dan Kewajiban Warga Negara.” 
Nahrowi. n.d. "Hak Dan Kewajiban Sebagai Warga Negara." Stkip Pgri Blitar. Perubahan Kedua Undang-Undang Dasar Negara Republik Indonesia Tahun 1945. (2016). From bssn.go.id: https://jdih.bssn.go.id/wp-content/uploads/2016/01/UUD1945PerubahanKedua.pdf

Nurcahyaningsih. (2015). Tinjauan Kriminologi Terhadap Perbuatan Main Hakim Sendiri. Jurnal Ilmu Hukum Legal Opinion, Volume 3, 1-9.

Nurgiansah, T. H. (2020). Filsafat Pendidikan. In Banyumas: CV Pena Persada.

Nurgiansah, T. H. (2021). Pendidikan Pancasila. In Solok: CV Mitra Cendekia Media.

Septia, C., Amelia, C., Aisyah, P., Zahira, R., \& Ika, W. (2021, Februari 2). Hak Kebebasan Berpendapat Yang Semakin Menyempit Dan Memburuk. Jurnal Syntax Fusion, 25-39..

UUD 1945 pasal 28 A-28J tentang Hak Asasi Manusia

Undang-Undang Dasar 1948 Pasal 27 Ayat 1, 2 dan 3

Undang-Undang Dasar 1948 Pasal 28A

Undang-Undang Dasar 1948 Pasal 28B Ayat 1 dan 2

Undang-Undang Dasar 1948 Pasal 28C Ayat 1 dan 2

Undang-Undang Dasar 1948 Pasal 28D Ayat 1, 2 dan 3

Undang-Undang Dasar 1948 Pasal 28E Ayat 1, 2 dan 3

Undang-Undang Dasar 1948 Pasal 28F

Undang-Undang Dasar 1948 Pasal 28G Ayat 1 dan 2

Undang-Undang Dasar 1948 Pasal 28J Ayat 1 dan 2

Undang-Undang Dasar 1948 Pasal 30 Ayat 1

Undang-Undang Dasar 1948 Pasal 31 Ayat 2 